\title{
Mongolia's Environmental Security
}

\author{
Chinese Unconscious Power and Ulaanbaatar's \\ State Weakness
}

\begin{abstract}
This article examines China's "unconscious power" over Mongolia's environmental sector. It argues that Ulaanbaatar's state weakness and Chinese unconscious power constitute a mutually reinforcing threat to Mongolia's environmental security.
\end{abstract}

KEYWORDS: Mongolia, China, environmental security, unconscious power

\section{INTRODUCTION}

Mongolia’s environmental security faces two fundamental, mutually reinforcing challenges. First, Mongolia's increasing economic dependence on China has allowed Beijing to develop what Strange called an "unconscious power" over Mongolia's environmental sector. This unconscious power manifests itself in Chinese demand for legal and illegal non-renewable resources, Chinese investment in environmentally harmful activities in Mongolia, and Chinese influence over the price of construction materials there.

Second, the Mongolian state [hereafter, "Ulaanbaatar," after the capital] is too weak to implement or enforce legislation aimed at mitigating environmentally harmful activities in Mongolia. This inability stems from the state's failure to control foreign influence on Mongolia's domestic affairs (interdependence

Jeffrey Reeves is Director of the Chinese Studies Center at the Center for Advanced Defense Studies in Washington, D.C. He has extensive experience working with political and social development in Asia with the United Nations and as a Peace Corps volunteer. He received his Ph.D. from the London School of Economics and Political Science in 20Io. Email: <jeff.reeves@c4ads.org>.

I. Strange describes unconscious power as the ability to exercise power "by 'being there' without intending the creation of exploitation of privilege or the transfer of costs or risks from oneself to others." See Susan Strange, The Retreat of the State (Cambridge, U.K.: Cambridge University Press, 1996).

Asian Survey, Vol. 5I, Number 3, pp. 453-47I. ISSN ooo4-4687, electronic ISSN 1533-838X. () 20II by the Regents of the University of California. All rights reserved. Please direct all requests for permission to photocopy or reproduce article content through the University of California Press's Rights and Permissions website, http://www.ucpressjournals.com/reprintInfo.asp. DOI: AS.20II.5I.3.453. 
sovereignty) and the state's ineffectiveness at organizing political authority (domestic sovereignty). ${ }^{2}$

Chinese unconscious power and Mongolian state weakness are mutually reinforcing. As China exerts greater influence through its unconscious power over Mongolia's environmental security, Ulaanbaatar's ability to attenuate the negative effects of this erodes. The weaker Ulaanbaatar becomes, the more unconscious power Chinese actors have over Mongolia's environmental security.

This is not to suggest that Beijing has enacted specific policy to expand China's unconscious power over Mongolia's environmental security. The diversity of Chinese actors and their activities in Mongolia implies that Chinese investment in Mongolia is not state-centric. Nevertheless, Beijing has identified Mongolia as a first destination for its "Go Out" policy (Chinese: Zou Chuqu Zhanlue), by which Beijing hopes to secure access to natural resources while expanding China's political influence. ${ }^{3}$ This prioritization implies that while a large number of Chinese actors in Mongolia do not receive direction from the Chinese government, they are nevertheless "unconscious actors" that contribute to Beijing's increasing unconscious power over Mongolia's economy and, consequently, its environmental security.

Responsibility for Mongolia's environmental security, however, ultimately lies with Ulaanbaatar. Beijing could not develop an unconscious power over Mongolia if Ulaanbaatar had sufficient sovereign institutions of control. Mongolian state weakness preceded Chinese unconscious power and is at least an equal threat to Mongolia's environmental security. This article draws on Buzan's definition of environmental insecurity as including issues involving the disruption of ecosystems, as well as problems of energy, population, food, and the economy. ${ }^{4}$ The paper looks at the role played by China's unconscious power and by Ulaanbaatar's state weakness in each sub-component of Mongolia’s environmental security.

2. Interdependence and domestic sovereignties are part of Krasner's four-part classification of sovereignty "types." This classification also includes international legal sovereignty and Westphalian sovereignty. See Stephen Krasner, Sovereignty: Organized Hypocrisy (Princeton, N. J.: Princeton University Press, 1999).

3. Central People's Government of the People's Republic of China (PRC), Youguan touzi Mengguguo kuangye yinggai zhuyi de wenti zhi yanjiu [We should research the problems of investing into Mongolia's mining industry], Central People's Government website, <http://www.gov.cn/wszb/ zhibo4I2/content_I7350I0.htm>, accessed December 15, 2010.

4. Barry Buzan, Jaap de Wilde, and Ole Wæver, Security: A New Framework for Analysis (Boulder, Colo.: Lynne Rienner Publishers, 1998). 


\section{DISTRIBUTIONS OF ECOSYSTEMS}

\section{Illegal Wildlife Trade}

Within the last 20 years, many Mongolian species have become extinct or been driven to the verge of extinction because of illegal hunting and animal trade. In 2005, the Wildlife Conservation Society and World Bank estimated that illegal trade in rare and very rare animal products in Mongolia had reached US\$IOO million annually. ${ }^{5}$ These products were principally fur and animal parts such as musk glands and horns used in Chinese traditional medicines. According to the report, the overwhelming majority of these animal products end up in Chinese markets.

The resulting effect on Mongolia's biodiversity has been catastrophic. For example, the Siberian marmot population, a species targeted for its fur, has decreased $75 \%$ in the past 12 years. In 2006, within Mongolian markets alone, the Mongolian Ministry of Environment uncovered more than 585,000 pelts despite an existing ban on marmot hunting. ${ }^{6}$ The Chinese dominate the marmot fur trade by buying the pelts in Mongolia, processing the fur in China's Inner Mongolia region, and reselling them on the Russian market. ${ }^{7}$ With little domestic demand for marmot fur in Mongolia, it is possible to directly attribute this dramatic decrease in marmot population to Chinese demand.

Other Mongolian animal species adversely affected by illegal trade are the red deer (population decline of $92 \%$ in I8 years); the Saiga antelope (declined $85 \%$ from 5,000 to 800 in I8 years); the argali (a wild mountain sheep, $75 \%$ in I8 years); and the Saker falcon (30\% in five years). ${ }^{8}$ All of these species, with the exception of the falcon, which has declined largely because of exports to $\mathrm{Ku}-$ wait, are hunted and traded for Chinese medicinal purposes. Moreover, the grey wolf, brown bear, Siberian ibex, Mongolian gazelle, wild boar, and Yakut moose are all in danger of becoming extinct because of increased prices offered in the Chinese market for game meat. Mongolian law either bans or severely restricts the hunting of all the forementioned species.

5. James Wingard and Peter Zahler, Silent Steppe: The Illegal Wildlife Trade Crisis (Washington, D.C.: World Bank, 2006).

6. World Wildlife Fund, Extent of Wildlife Trade in Mongolia: Facts and Figures, World Wildlife Fund website, <http://mongolia.panda.org/en/threats/wildlife_trade/>, accessed October 7, 2010.

7. Author's interview with a staff member of the Mongolia-based Coping with Desertification Project (CODEP), February I, 2008, Ulaanbaatar.

8. Wingard and Zahler, Silent Steppe. 
Illegal traffic and trade of wildlife are among the greatest threats to Mongolian biodiversity - and some of the most profitable enterprises for Mongolian hunters. ${ }^{9}$ While hunters and local government officials ultimately bear responsibility for this jeopardy, Chinese smugglers and wildlife traders are the principle sources of demand.

Despite the growing evidence that Mongolia's illegal trade is flourishing because of Chinese demand, the Mongolian government has done little to stanch the flow of illegal goods across the border. The government does impose restrictions on the number of animals that can be legally hunted, but enforcing these restrictions is next to impossible. Solo hunters do most of the poaching, and Mongolian law excuses all killing of animals so long as the hunters claim the animals are endangering their herd.

\section{Desertification}

The Swiss Agency for Development and Cooperation in Mongolia estimates that desertification affects $44 \%$ to $90 \%$ of the country's territory. ${ }^{10}$ A principal cause of desertification is the exponential growth of goats since the country's transition from socialism in 1990 . Even though traditional Mongolian herding practices sought to limit goats to less than IO\% of a total herd to ensure pastureland sustainability, goats accounted for more than half of Mongolia's total livestock in 20I0. ${ }^{11}$ Goats damage pastureland by breaking up topsoil with their sharp hooves and snouts, and they tear plants and grasses out by the roots rather than merely eating the aboveground vegetation. Deserts are often the result.

Chinese demand for raw cashmere is driving the increase of goat populations in Mongolia. ${ }^{12}$ In 2005, Beijing announced that it planned mandatory reductions in sheep and goat populations as a percentage of overall herds in China's Inner Mongolian Autonomous Region (IMAR) to arrest progressive

9. Author's interview with an East Asian environmental specialist, World Bank, May I8, 2008, Ulaanbaatar.

IO. Author's interview with a staff member of the Swiss Agency for Development and Cooperation, "Coping with Desertification Project in Mongolia," Project Lead, March I2, 2008, Ulaanbaatar.

II. World Bank, Dzud: A Slow Natural Disaster Kills Livestock and Livelihoods in Mongolia, $<$ http://blogs.worldbank.org/eastasiapacific/dzud-a-slow-natural-disaster-kills-livestock-and-livelihoodsin-mongolia>, accessed October 8, 2010.

12. Vera Songwe and Bold Magvan, From Goats to Coats: Institutional Reform in Mongolia's Cashmere Sector (Washington, D.C.: World Bank, 2003). 
desertification. ${ }^{13}$ Concurrently, Chinese officials outlined the government's objective of maintaining control over the entire value-added supply chain for cashmere. ${ }^{14}$ In order to achieve both objectives, Beijing planned to boost imports of raw cashmere. Mongolia, the second largest producer of raw cashmere in the world after China, borders the IMAR, so it is likely Chinese officials saw their neighbor as the principal source for imports.

At present, more than half of Mongolia's raw cashmere is exported to China for processing. As a result, Mongolia’s domestic processing facilities are deteriorating and can no longer compete in adding value to the wool. Many cashmere producers have responded to the decline in domestic capacity by shifting from producing quality processed cashmere to producing more raw cashmere. ${ }^{15}$ This trend will lead to Mongolia's increasing desertification and greater economic dependency on China.

Ulaanbaatar has sought to address desertification through regional and international partnerships and requests for development aid. It is an active participant in a variety of established programs, including the U.N. Convention to Combat Desertification, the Asian Development Bank's (ADB) "Prevention and Control of Dust and Sandstorms in Northeast Asia," and the Swiss Agency for Development and Cooperation's "Coping with Desertification Project in Mongolia." ${ }^{16}$ Representatives from Ulaanbaatar are regular attendees at regional conferences such as the Northeast Asian Conference on Environmental Cooperation (NEAC). The Mongolian government also receives considerable aid from the ADB, Japan, China, and South Korea aimed at addressing Northeast Asian sandstorms.

Notably, Mongolia has not been asked to participate in the region's most concerted effort to address desertification and sandstorms, the Tripartite Environmental Ministers Meeting (TEMM). Although the group, consisting of China, Japan, and South Korea, has consulted on the drafting of its "Regional Master Plan for the Prevention and Control of Dust and Sandstorms in

13. Karl Zimmerer, Globalization and New Geographies of Conservation (Chicago, Ill.: University of Chicago Press, 2006).

14. Caroline Humphrey and David Sneath, The End of Nomadism? Society, State, and the Environment in Inner Asia (Durham, N. C.: Duke University Press, 1999).

15. Donald Lecraw, Philip Eddleston, and Alene McMahon, A Value China Analysis of the Mongolian Cashmere Industry (Ulaanbaatar: USAID [U.S. Agency for International Development], 2005).

16. ADB, "Prevention and Control of Dust and Sandstorms in Northeast Asia," ADB website $<$ www.adb.org/Documents/Brochures/pcdsna/pcdsna.pdf>, accessed January 7, 201. 
Northeast Asia" with the Mongolian government, TEMM is otherwise quite exclusionary in terms of cooperating with Ulaanbaatar. Mongolia's exclusion from the TEMM suggests that the group's permanent members view Ulaanbaatar as too politically and materially weak to support their efforts.

\section{ENERGY PROBLEMS}

\section{Illegal Logging}

Although it is impossible to measure the precise extent of illegal logging in Mongolia, the estimates are staggering. The government's National Statistics Office (NSO) estimates average timber consumption, including legal and illegal production, at around 5.5I million cubic meters, about five times the sustainable annual harvest volume. ${ }^{17}$ To put this amount into perspective vis-à-vis average national predicted consumption, the Mongolian government has restricted annual legal harvest limits to 617,200 cubic meters, oneninth the actual estimated amount used.

The majority of the illegal timber is sold into the Chinese markets. ${ }^{18} \mathrm{Be}-$ cause China is now the largest importer of wood in the world, with an annual deficit in the amount needed for economic growth of 75 million cubic meters, we may logically conclude that such demand leads to increased illegal logging in Mongolia. This trend fits with Chinese international lumber imports. Domestic restrictions regarding logging have forced businesses in the PRC to look to less-developed countries in Asia and Africa for both legally and illegally harvested wood. ${ }^{19}$

In 2005, the Mongolian government passed legislation eliminating tariffs on imported lumber while doubling the cost of domestically produced wood products in an effort to discourage lumber product exports. This legislation has had limited success because Ulaanbaatar lacks the internal capacity to enforce the regulation. Constant changes in personnel and mandates in the forestry sector have led to a breakdown in the institutional base, from which no single ministry has emerged as the key regulator. Competition among ministries for resources has meant that no single institution has the ability to

I7. Magda Lovei and Arshad Sayed, Wood Supply in Mongolia: The Legal and Illegal Economies (Washington, D.C.: World Bank, 2006).

I8. East Asian environmental specialist interview.

19. Chris Alden, China in Africa: Partner, Competitor, or Hegemon? (London: Zed Books, 2007). 
enforce the government's sweeping protective laws. ${ }^{20}$ The result is continued illegal logging, not only in those areas designated for production but also in Mongolia's most sacred and protected areas such as Khovsgol Lake in the boreal taiga forest.

\section{Hydroelectricity}

Although Mongolia derives less than 3\% of its overall energy from hydroelectricity, the Ministry of Fuel and Energy plans to dam as many as 20 smaller rivers to expand hydroelectric capacity. Part of the national renewable energy program, the damming is aimed at providing remote areas with a steady supply of energy that is not dependent on coal. The cost-benefit breakdown of this government initiative is questionable. The hydroelectric sector is underdeveloped because past attempts were crippled by the fact that Mongolia's rivers remain frozen for most of the year. Moreover, the country's numerous rivers and streams are small, with a weak flow capacity. Many are drying up because of water demands from Ulaanbaatar, global warming, desertification, and deforestation. Past attempts to dam rivers in Mongolia resulted in water shortages and the destruction of flora and fauna. In one instance, the damming of a river near Olgii Lake cut off the water supply for an entire village, forcing it to relocate. ${ }^{21}$

The real impetus behind the government's push to build dams raises many questions. While 17 of the projected sites are still in the initial planning phase, three sites—Durgon, Taishir, and Orkhon—are currently under construction in western and central Mongolia. Of those, the Durgon and Orkhon Dams are wholly or in part Chinese-initiated and -financed.

The Chinese firm China Water-Conservancy Investment Company is financing the Durgon Dam on the Chono-Kharaikh River in western Mongolia. ${ }^{22}$ The project's stated purpose is to provide energy for western Mongolia, with the goal of reducing the country's energy dependency on Russia. The project has generated huge opposition from local residents and civil society, who worry about the environmental effects and the dam's real

20. N. Batsukh, Mongolian Forest Ecosystems (Ulaanbaatar: World Wildlife Fund, 2008).

2I. Ts. Tsevenkherlen, "Ogii Nuur Olsoj Ehellee" [Ogii Lake gets hungry], Onooder [Today] (Ulaanbaatar), January 25, 2007.

22. China Shanghai Corporation for Foreign Economic and Technological Cooperation (SFECO), Duragun Hydroelectric Power Station in Mongolia, China SFECO Group website, <http:// www.sfeco.net.cn/e/trade/detail.asp?id=I4990>, accessed October 7, 2010. 
value. These concerns were reinforced by a World Wildlife Fund-sponsored socioeconomic assessment and economic cost-benefit analysis, both of which strongly cautioned against the project. ${ }^{23}$

The Orkhon Dam is also partially Chinese financed, and is another questionable hydroelectric project. Non-governmental organizations (NGOs) and international organizations in Mongolia widely regard the dam as a Chinese pet project with no real benefits for Mongolia other than supplying power to the copper mines in the south. ${ }^{24}$ This perception comes from the fact that the London-headquartered international mining group Rio Tinto, of which the Aluminum Corporation of China (Chinalco) owns 9\%, is involved in the mining and is negotiating a direct rail line from the mines to the IMAR in China.

The Chinese government benefits from dam building both commercially and strategically. ${ }^{25}$ Chinese businesses, often government run, have undertaken similar dam building projects in Africa and Southeast Asia to secure access to resources. This is the case with Chinese dam construction in Laos, Cambodia, Mozambique, Sudan, and Zambia. ${ }^{26}$ Chinese dam building has at times contributed to environmental degradation, forced migration, and human rights abuses in these countries. ${ }^{27}$ Although Mongolia has extensive laws regarding fees for water and mineral water use, including provisions for taxing income derived from hydroelectric production, there are currently no legal restrictions on who can construct a dam and under what circumstances. This stark omission of government regulation has allowed projects to go forward without environmental impact assessments (EIA).

\section{POPULATION PROBLEMS}

Dependency theory explains population problems in least developed countries by examining the role variables such as industrialization of the periphery's core, overreliance on foreign capital, and economic stagnation in remote

23. World Wildlife Fund, WWF-Mongolia Position on Proposed Durgon Hydropower Plant (Ulaanbaatar: World Wildlife Fund, 2003).

24. Author's interview with a staff member of the United Nations Development Program, March 7, 2008, Ulaanbaatar.

25. Philip Hirsch, "The Changing Political Dynamics of Dam Building on the Mekong," Water Alternatives 3:2 (June 200I), pp. 312-23.

26. Stephen Marks, African Perspectives on China in Africa (Nairobi: Pambazuka Press, 2007); Hirsch, "The Changing Political Dynamics of Dam Building on the Mekong."

27. Marks, African Perspectives on China in Africa. 
areas play in mass in-migration and urbanization. ${ }^{28}$ Dependency theory assumes an urban bias in foreign investment that results in an increased accumulation of capital in large cities and a resulting rural brain drain as labor forces leave the countryside. The consequences of this type of population movement are decreased economic activity in poor, isolated areas and increased burdens on urban resources.

Further, dependency theory notes that as more and more people move toward urban areas in search of economic opportunity, urban populations experience high levels of unemployment, decreased quality of services, and an increase in material inequality. ${ }^{29}$ Rather than contributing to the development of cities, in-migration resulting from economic dependency causes the deterioration of infrastructure and social services such as health care, education, and sanitation. Dependency theory explains this by noting that when much of a country's wealth is exported to core states, the ability of the dependent state's government to provide social goods is undermined.

In this regard, dependency theory is relevant to understanding Mongolia's post-transition population problems, particularly in-migration and urbanization, because the socioeconomic consequences have largely been negative. The ADB notes that in-migration and urbanization in Mongolia since I99I have been the direct result of the country's transition to capitalism and increased economic opportunity in Ulaanbaatar, so assuming an economic motivation behind the phenomena is appropriate..$^{30}$ This perception further implies that foreign direct investment and foreign trade have been the primary drivers behind the country's demographic shift.

While it is not possible to attribute Mongolia's in-migration directly to its economic dependency on China, the countries' relations do play an important enough role in Mongolia's domestic economy that this variable must be considered. Of course, the ultimate responsibility for the worsening environmental conditions in Ulaanbaatar caused by population strain rests with the Mongolian government. But as a weak state, Ulaanbaatar has only a limited capacity to mitigate such deteriorating conditions.

28. David Alan Smith, Third World Cities in Global Perspective: The Political Economy of Uneven Urbanization (New York: Westview Press, 1996).

29. George Mclean and John Kromkowski, Urbanization and Values (Washington, D.C.: Council for Research in Values and Philosophy, I991).

30. Ramesh B. Adhikari, Mongolia: Urban Development Sector (Ulaanbaatar: ADB, 2009). 


\section{Uncontrollable Migration}

An estimated one-half of Mongolia's 3.I million population lives in or around Ulaanbaatar, with more residents leaving the countryside each year for the capital. Proportionally, the resulting concentration is matched in Asia only by Bangkok, where one-quarter of Thailand's population lives. At present an average of around 25,000 new residents arrive in Ulaanbaatar annually, and the numbers are increasing every year. ${ }^{31}$ In a speech presented at the 2005 National Summit of Migration, Mongolia’s Minister of Health, Sambuu Lamdaa, called the current in-migration a direct threat to national security. ${ }^{32}$

Key challenges of this in-migration for Ulaanbaatar are increased pressures on existing urban infrastructure and the transfer of rural to urban poverty. Many migrants to Mongolia's capital are former herders who have lost their livestock through harsh winters or economic concerns, and they often lack the skills to make the transition from animal husbandry to the service sector. ${ }^{33}$ In this regard, uncontrolled migration from the countryside to Ulaanbaatar is a two-fold social and development challenge for the Mongolian government: both the city and rural areas suffer economically, environmentally, and socially as a result.

Mongolian legislation is laissez-faire in addressing the issue of in-migration. According to the 1992 Constitution, Mongolian citizens have the freedom to move and live where they wish, without constraint or regulation. Ulaanbaatar is, therefore, constitutionally limited as to what it can do. Thus far, the government has attempted to record, not control, migration with a series of registration laws. The key document is the 2004 Rules of Registration of People Moving in Mongolia, which requires any new resident to register with the local municipal authorities after 180 days in a new location.

Another indirect method used by Ulaanbaatar in an attempt to address the migration issue is encouraging regional development. In its $2003 \mathrm{Law}$ on Regionalized Management and Coordination, Ulaanbaatar specified eight "pillar cities" that could serve as economic alternatives for migrants who wish to resettle from the countryside. Although the government allocated US\$500,000

3I. Author's interview with an assistant representative of Mongolia's United Nations Population Fund (UNFPA), March Io, 2008, Ulaanbaatar.

32. UNFPA, National Summit on Migration, UNFPA News website, <http://mongolia.unfpa. org/2009/08/04/I046/decision_makers_urged_to_invest_in_women/>, accessed October 7, 2010.

33. ADB, Central Asian Regional Economic Cooperation (CAREC) Regional Trade Facilitation Program, <http://www.adb.org/projects/tradefacilitation/default.asp >, accessed October 7, 2010. 
for the project that year, by zoio none of the eight pillar cities showed a net increase in in-migration; many continued to show population loss.

\section{Urbanization}

Mongolia's uncontrolled migration over two decades has resulted in unplanned and unsustainable urbanization. The rapid influx of rural residents to Ulaanbaatar, initially conceptualized to accommodate 500,000 people but now home to nearly I.5 million, is straining every aspect of the city's infrastructure. From waste management and water to accommodations and health services, the capital's resources cannot meet the increase in demand.

In response, in $200 \mathrm{I}$ the national government and the capital's top officials agreed on a long-term development plan for the capital called the Ulaanbaatar City Development Strategy (CDS). While theoretically a step forward, the CDS has proven to be nothing more than a collection of 26 vision statements—without any clear budget allotments, implementation plans, or specific ministerial or departmental ownership. Moreover, the plan failed to address concretely many key issues: education, health, water, sanitation, or land tilling, nor did it conduct an EIA. The CDS has effectively been dead since $200 \mathrm{I} .^{34}$

The lack of a comprehensive, much needed approach to urban planning has left Ulaanbaatar essentially fending for itself. New residents show up each year with little or no realization of the effects their arrivals have on the city or the surrounding environment. A major result, in addition to increased traffic, air, water, and noise pollution, is huge growth in the city's ger (yurt) districts, or shantytowns. These ger districts, home to more than $80 \%$ of new arrivals, are by far the greatest challenge stemming from urbanization: They lack the infrastructure for sanitation, from solid waste collection to water access. ${ }^{35}$

Air pollution is of key importance when considering the effects the ger districts have on Ulaanbaatar's environmental health. Industry and construction within the city limits, plus the use of leaded gasoline for cars, contribute to the poor air quality. But the burning of high-pollutant fuels in the ger districts is the real source of high concentrations of airborne particles. ${ }^{36}$ The

34. East Asian environmental specialist interview.

35. Ts. Tsevenkherlen, "Ogii Nuur Olsoj Ehellee."

36. Mongolian Ministry of Environment, Agaariin Bohirdol [Air pollution], <http://www.mne.mn/ $\mathrm{mn} /$ index.php?option=com_content\&view=article\&id=63\&Itemid=196.>, accessed October 7, 2010. 
Ministry of Environment found that rather than using coal for heating and cooking, a large number of impoverished families had taken to burning trash and rubber tires. ${ }^{37}$ The noxious chemicals released from such fuels has boosted air pollution in the ger districts to five times the levels found in areas where coal is the primary fuel.

The ger districts' growth has also contributed to a lack of access to clean water throughout Ulaanbaatar. Because the city is flanked on its north and south sides by mountains while being open to the east and west, it would seem logical for urbanization to spread outward. Yet, the opposite has proven true: the ger districts have spread up and into the mountains. The environmental effect of this urban spread is that water pollutants from the ger districts are funnelled downward into the city's central groundwater supplies. These polluted conditions have also led to increased health related issues that are specific to ger district residents. Indeed, the Mongolian office of the World Health Organization (WHO) reports that non-communicable conditionscancer, cardiovascular disease, injuries, and poisoning-are more prevalent in the ger districts than before, and are likely to increase. ${ }^{38}$

\section{Housing}

The concentration of new arrivals to Ulaanbaatar in the ger districts is the result of a lack of affordable urban housing. Between 2007 and 2008, the average cost per square meter for an apartment in Ulaanbaatar almost doubled from $\$ 350$ to $\$ 650 .{ }^{39}$ Ulaanbaatar's housing problems are the result of the rising cost of domestic building materials such as steel and wood, stemming from Chinese regional demand and Mongolian companies' inability to produce bricks and cement, both of which are imported from China, at a competitive cost. ${ }^{40}$ The increased costs of materials from China contributed to the difficulty that the Mongolian Ministry of Construction had in launching its “40,000 New Flats" program, aimed at providing centrally located, low-cost housing in the capital to more than Ioo, ooo residents currently living in the ger districts.

37. E. Enkhma, "Yaduu Orhuud Rezinen Dugui Tulj Baina" [Poor families burn rubber tires], Onooder, January 3, 2008.

38. WHO, Country Cooperation Strategy (Ulaanbaatar: WHO, 2008).

39. Enkhma, "Barilgiin Materialiin Uildverleliig Demjvel Uls Hurdan Hogjino" [Support of domestic construction will help development], Onooder, January 17, 2008.

40. Author's interview with the director-general of the National Center for Construction, Urban Development, and Public Utilities, Mongolian Ministry of Construction, May I8, 2008, Ulaanbaatar. 
While never a viable development strategy, "40,000 New Flats" is worth examining because the Mongolian press presents it as a prototypical example of how Mongolia's urban development is entirely dependent on conditions outside its control. Media in 2006 reported that once former Prime Minister Miyeegombyn Enkhbold and other government officials announced the program, prices for Chinese bricks leapt from seven cents to 20 cents each, while the cost of a bag of cement doubled. ${ }^{41}$ This forced the government to suspend the program indefinitely.

Such evidence is not, of course, enough to charge that Chinese regional demand caused the project to fail. It is, however, an example of how Mongolia's economic dependency on China can undermine domestic development initiatives and contribute to population problems. That Ulaanbaatar's initiatives tend to fail in the face of rising materials costs spurred by Chinese demand suggests the need for continuing attention to such problems. The lack of housing contributes greatly to the overall poor quality of Mongolia's environment.

\section{FOOD PROBLEMS}

Economic dependence on China exacerbates Mongolia's food problems, including scarcity, lack of domestic production, and food safety issues.

\section{Domestic Production and Foreign Food Dependency}

Food, more than any other import, is where Mongolia is dependent on the Chinese market. Although a small percentage of cereals and breads comes from Russia, more than $90 \%$ of non-meat foods in Mongolia originate from China. These include poultry and fish, vegetables, fruit, tea, rice, wheat flour, sugar, soft drinks, and beer-all difficult or impossible to produce in Mongolia itself. ${ }^{42}$ One need look no further than the local markets for evidence that Chinese victuals dominate Mongolia's food imports: more labels are written in Chinese than in Mongolian.

This dependency has led to a dramatic decrease in domestic crop production. As of 2009, a bumper crop year, Mongolia's crop production covered

4I. Enkhma, "Hariihand Barcaalagdsan Hotolbor" [Foreign secured government contracts], Onooder, January 2I, 2008.

42. Mongolian Ministry of Foreign Affairs, Current Status of Industry, <http://www.mofa.gov. $\mathrm{mn} / \mathrm{mn} />$, accessed October 7, 2010 . 
less than 250,000 hectares, almost 300,000 hectares lower than in $1990 .{ }^{43} \mathrm{~A}$ 2OII FAO country brief registers crop production in Mongolia in 2010 as declining II\% from 2009 levels. ${ }^{44}$ A 20II World Bank economic update noted three consecutive quarters of double-digit contractions in Mongolia's agricultural industry. ${ }^{45}$

The Mongolian government has not taken policy action aimed at increasing domestic crop production. ${ }^{46}$ In fact, all trends in food production and imports indicate that Mongolia will grow increasingly dependent on Chinese imports to meet even basic food needs at a national level.

\section{Food Safety}

Of central concern for food safety in Mongolia is the lack of control measures in place for food related imports, most of which come from China. Bulk foods are brought in in unrefrigerated freight containers not designed for transport of perishable items, so more than half arrive in Ulaanbaatar either not frozen, expired, or contaminated. ${ }^{47}$ But because an increasing amount of food comes from China not in bulk shipments but via individual traders, it is impossible for Mongolian border officials to inspect all incoming food supplies. According to J. Enkhbayar, vice-director of Mongolia’s Food and Drug Administration, less than Io\% of all food imports from China are checked. ${ }^{48}$

In 2006, the Mongolian delegation to the World Trade Organization (WTO) Sanitary and Phytosanitary Measures Conference circulated a memorandum highlighting Mongolian official efforts to improve food safety. Key legislation mentioned included the 1999 Food Safety Law that defined the rights and responsibilities of domestic food producers, set product standards, and established the State Specialized Inspection Agency in 200o. Yet,

43. Food and Agricultural Organization (FAO), Mongolian Primary Crops: Area Harvested: 1990-2009, FAOSTAT website, <http://faostat.fao.org/site/567/DesktopDefault.aspx?PageID= 567\#ancor>, accessed April 5, 20II.

44. Idem, GIEWS Country Brief: Mongolia, FAO website, <http://www.fao.org/giews/countrybrief/country.jsp?code=MNG $>$, accessed April 5, 20II.

45. World Bank, Mongolia: Quarterly Economic Update, World Bank website, <http://siteresources.worldbank.org/INTMONGOLIA/Resources/Mongolia_Quarterly_Economic_Update_ final.pdf>, accessed April 5, 20II.

46. Author's interview with FAO representative, Mongolia, March 25, 2008, Ulaanbaatar.

47. FAO and WHO, Regulatory Issues: Food Safety Situation in Mongolia, <http://www.fao.org/ docrep/meeting/oo4/ab42oe.htm>, accessed October 7, 2010.

48. X. Bolormaa, "J. Enkhbayar: Arkhitai Holbootoi Hereg Uusch, Asuudal Bossond Bayarlaj Baina" [J. Enkhbayar: I'm pleased renewed attention is being paid to vodka issues], Onooder, January Iо, 2008. 
according to a joint FAO-WHO report on Mongolia's food safety published only two years later, enforcement of Mongolia's Food Safety Law was incomplete. The study noted that inspection committees consistently failed to take into account the various stages of food production, instead focusing only on the end product. ${ }^{49}$

\section{ECONOMIC PROBLEMS}

\section{Mining}

Mongolia's mining sector remains the country's main source of environmentally harmful economic activity. But more worrisome than the effect almost every aspect of the industry has on the ecosystem is how quickly the damage has occurred. Mining in Mongolia took shape only at the beginning of the 2Ist century, yet its environmental consequences are so acute that whole rural areas have become essentially uninhabitable. Water pollution, air pollution, encroachment on protected areas, mercury poisoning, land degradation, loss of biodiversity, soil erosion, and landscape destruction are just some of the outcomes of mining. ${ }^{50}$ And far from successfully regulating the industry, the government has unwittingly encouraged illegal, harmful mining through the introduction of high windfall taxes and the insistence that all gold mined in Mongolia must be sold to the Mongol Bank at a fixed price. In this sense, many companies, and certainly the artisan miners-individuals engaged in small-scale illegal mining-find it much cheaper and far more practical to operate completely outside the regulated mining industry.

The greatest threat to Mongolia's environment comes from small- and medium-sized mines. While the domestic media pays a great deal of attention to the larger mines like Oyu Tolgoi, the companies responsible for their development, such as Ivanhoe Mining and Rio Tinto, tend to follow international best practices. These companies also employ the most sophisticated technologies, developed to minimize environmental impact, while the opposite is true for Mongolia's smaller-scale mines.

Some government officials believe that Chinese investors, acting through Mongolian citizens, control the majority of small- and medium-sized

49. FAO and WHO, Regulatory Issues.

50. Giovanna Dore et al., A Review of the Environmental and Social Impacts of the Mining Sector (Washington, D.C.: World Bank, 2006). 
mines. ${ }^{51}$ While it is impossible to know the full extent of Chinese partial or full ownership, fully owned Chinese firms operating in Mongolia have poor records of environmental protection. Two prime examples are the Da Chin firm in Dornod and the Ten Khun in Jargalant. Both companies have been accused of widespread environmental damage caused by illegal drainage of polluted water, illegal digging, and careless explosions, which, in one case, left two Mongolian miners dead. When confronted, the Chinese staff denied any knowledge of Mongolian law, claiming they could neither read nor write Mongolian. ${ }^{52}$

Of even greater environmental concern are Mongolia's "ninja” miners, or artisan placer gold miners, who destroy large swathes of the countryside by digging countless holes, poisoning water with mercury and sodium cyanide (used to winnow gold from small stones), and leaving behind unprocessed waste and makeshift shanty villages. While their activities are completely illegal, those involved in artisanal mining number close to roo,ooo. Ninja miners operate outside Mongolian society and law, using child labor, ignoring safety standards, and relying on informal institutions to deal with disputes or crime. Nearly all ninja-collected gold and fluorspar goes directly to China, allowing the ninjas to operate almost entirely outside Mongolia's formal economy. The Mongolian government has been unable to mitigate their ecological damage..$^{53}$

This is not to imply that Ulaanbaatar does not have a substantial legal framework in place for mining licensing and exploration. The laws regulating mineral exploration and extraction are extensive and seemingly quite focused on ecosystem protection. There are, however, several provisions included in legislation aimed at the mining industry that allow for a level of exploitation. These loopholes have benefited domestic and foreign (almost exclusively Chinese) firms equally. Principal among these loopholes is the "state" licensing exemption. While an individual is required to apply for a permit, anything related to state exploration is permissible without a license. ${ }^{54}$ Because the responsibility to determine what constitutes a state interest is

51. Author's interview with the counselor of Policy, Information, and Monitoring, Mongolian Ministry of Foreign Affairs, March I, 2008, Ulaanbaatar.

52. B. Aruna, "Jargalant Suirliin Irmegt Tuljee" [Jargalant faces disaster], Onooder, November I, 2007.

53. Dore et al., A Review of the Environmental and Social Impacts of the Mining Sector.

54. Bayarmaa Tserendavaa, Compendium of Laws: A Mongolian Citizens Reference Book, Asia Foundation, <http://waterwiki.net/images/2/27/Compendium_of_Laws_english.pdf $>$, n.d. 
decentralized and ultimately rests with regional officials—who often have financial stakes in regional mining operations-corruption is common. ${ }^{55}$ For example, in 2008, Onooder, one of Mongolia's most prestigious newspapers, published a report on corruption among officials in the Bogdkhan Mountain Special Protected Area. The report found that these officials granted permits to 157 entities ranging from individuals to small, privately owned foreign and domestic companies, to operate in or around Bogdkhan in exchange for payment. The report noted that the I57 entities had spread into the protected area, rendering the surrounding environment "unrecognizable," all under the auspices of acting in line with "state interests." The central government, in response to the report's initial findings, said it would nullify all 157 licenses and investigate those responsible for their issuance. The reporter, however, concluded by stating that the government routinely makes such promises but does not follow through. ${ }^{56}$

\section{CONCLUSION}

Ulaanbaatar's inability to pass legislation to protect Mongolia's environmental health, secure its borders against the flow of illegal trade, and enforce existing laws all indicate that the state's sovereignty is weak. This weakness not only harms the state's capacity to protect Mongolia's environment but also its ability to mitigate foreign influence on its environmental security. Such state weakness is central to the challenges Mongolia now faces in regard to its environmental health. It is not, however, the only component.

Equally influential is the growth in Mongolia of Chinese unconscious power. Although this is not state-centric, the expansion of Chinese actors in Mongolia is the result of Beijing's "Go Out" strategy. This suggests that while it would be unfair to blame Beijing for Mongolia’s worsening environment, it would also be inaccurate to imply that the Chinese government has no agency in Mongolia's environmental security.

Taken together, Mongolian state weakness and Chinese unconscious power pose a great threat to Mongolia's environmental security. This conclusion implies that any solution to Mongolia's environmental problems will require a comprehensive approach involving both governments. At present, there is

55. Dore et al., A Review of the Environmental and Social Impacts of the Mining Sector.

56. Ts. Tsevenkherlen, "Zarligaar darhalsan Bogdkhan uuland huuli uilchleh bolov uu?" [Will current laws protect Bogdkhan Mountain?], Onooder, January 2I, 2008. 
little reason to hope such a development will take place. Ulaanbaatar is currently faced with a weak state's dilemma of whether economic growth is more important than resource protection. Clearly, the state has failed to enforce existing legislation aimed at protecting the environment, choosing to follow other underdeveloped Asian and African states in sacrificing environmental health for potential financial gain. ${ }^{57}$

As with other regional cores, Beijing has the potential to support its neighboring countries while encouraging trade, just as it has the potential to encourage unsustainable resource exploitation. The European Union (EU) is a case in point of a regional power center demanding good environmental practice as a condition for increased trade and social interaction with its neighbors.

The EU's policy of exporting best environmental practices is particularly true in the case of Eastern European countries such as Poland, Hungary, Bulgaria, Romania, Slovakia, and the Czech Republic. Following the collapse of international communism in the early I990s, these countries were all left with extremely damaged environments. Rather than seek to exploit their transitional economies, more-affluent members of the EU demanded that the Eastern European states adopt better environmental protection policies and improve their environments, in order for their membership bids to be considered. As a result, the applicant countries raised their environmental standards to match the EU requirement and achieved membership into the larger economic community. ${ }^{58}$ The EU has served as a regional core promoting sustainable European environmental policy through economic inducement.

The opposite is true for China. Rather than encouraging Mongolia to adopt environmentally sustainable practices, Chinese companies have taken advantage of Ulaanbaatar's weakness to exploit the country's resources. Chinese businesses have invested in Mongolia and operated outside Mongolian law when it has proven to be profitable. Chinese border officials have failed to help curb the cross-border flow of illegal goods ranging from animal parts to timber. Far from using its central position in Asia to act as a model for eco-conscious development, Beijing has allowed its domestic companies to export bad environmental practices while consuming massive amounts of neighboring countries' resources.

57. Morris Rossabi, "Transmogrification of a Communist Party," Pacific Affairs 82:2 (Summer 2009), pp. 23I-50.

58. Andrew Jordan, Environmental Policy in the European Union (London: Earthscan, 2005). 
Again, it is necessary to acknowledge that Beijing does not control the Chinese actors engaged in environmentally damaging activities in Mongolia. Nevertheless, the Chinese Communist Party is China's paramount power, with direct authority over domestic industry, and could institute standards over Chinese actors abroad that would lessen their environmental impact. Ultimately, Beijing will find itself in a position where such control is no longer an option but a necessity. Environmental security is a transnational issue that requires a transnational approach. Beijing's participation in TEMM shows that it understands the need for multilateralism when addressing transnational environmental issues such as desertification and sandstorms. It is simply a question of when Beijing will decide that the cost of cross-border environmental problems outweighs the benefits of using Mongolia's natural resources.

Overcoming such regional constraints is critical for Mongolia. Its natural resources are not only part of its social identity but also the crux upon which the state's economy is centered. The sustainability of the country's nomadic lifestyle will certainly prove impossible without greater care being placed on land management and domestic agricultural production. At present, Ulaanbaatar must decide whether continual economic growth is worth environmental insecurity. Such a choice will require a more forward-looking government with solid sovereign control. 